\title{
Phytochemical Analysis and Antifungal Activity of Fruit Leaves Extracts on the Mycelial Growth of Fungal Plant Pathogens
}

\author{
Ayman Y El-Khateeb ${ }^{1}$, Elsherbiny A Elsherbiny ${ }^{2 *}$, Louis K Tadros ${ }^{1}$, Safaa M Ali ${ }^{1}$ and Hassan B Hamed ${ }^{1}$
}

${ }^{1}$ Agricultural Chemistry Department, Faculty of Agriculture, Mansoura University, Mansoura, Egypt

${ }^{2}$ Plant Pathology Department, Faculty of Agriculture, Mansoura University, Mansoura, Egypt

\begin{abstract}
Methanolic extracts of leaves of thompson seedless grape, flame seedless grape, zizyphus, pomegranate and fig were screened for their phytochemical constituents and also investigated for their antifungal activity in vitro against phytopathogenic fungi, Alternaria solani, Botrytis cinerea, Botrytis fabae, Fusarium oxysporum and Fusarium solani. Phytochemical screening of crude methanolic extracts revealed the presence of terpenes, tannins, flavonoids, alkaloids, carbohydrate or glycosides, phenolic glycosides and resins in all extracts, while saponins were not detected from any extracts except zizyphus and fig. Zizyphus leaves had the highest concentration of total polyphenols and total flavonoids content which were $147.47 \mathrm{mgGAE} / \mathrm{g}$ and $16.35 \mathrm{mgQE} / \mathrm{g}$, respectively. HPLC analysis identified twelve polyphenolic compounds; pyrogallic acid, gallic acid, protocatechuic, catechin, $p$-hydroxy benzoic acid, $p$-coumaric acid, phenol, o-coumaric acid, salicylic acid, coumarin, quercetin and cinnamic acid. All extracts contained protocatechuic, catechin, $p$-hydroxy benzoic acid, $p$-coumaric acid, o-coumaric acid and coumarin with different concentrations. The methanolic extract of zizyphus leaves had the greatest inhibitory effect on mycelial growth of $B$. fabae by $95.56 \%$ at $4 \mathrm{mg} / \mathrm{ml}$. Also, extract of pomegranate caused remarkable reduction on the fungal growth $(94.44 \%)$ of $B$. fabae at $4 \mathrm{mg} / \mathrm{ml}$, while fig extract caused $91.11 \%$ inhibition against the same fungus at the same concentration. F. oxysporum and $F$. solani were the most resistant fungi against all methanolic extracts tested.
\end{abstract}

Keywords: Antifungal activity; Plant extracts; Phytopathogenic fungi; Phytochemicals; HPLC

\section{Introduction}

The damage to crops caused by fungal plant pathogens has required the use of range of antifungal control agents. Among pesticides used to protect crops, fungicides were perceived until recently as relatively safe. However, the 1986 National Academy of Sciences (NAS) report on pesticide residues on food indicated that fungicides pose more of a carcinogenic risk than insecticides and herbicides together [1]. Furthermore, the use in crop protection of many synthetic fungicides that have various degrees of persistence has now been cautioned due to their carcinogenicity, teratogenicity and other residual toxicities. Several of the synthetic fungicides are reported to cause adverse effects on treated soil ecosystems because of their non-biodegradable nature [2,3]. Synthetic fungicide residues are suspected to present a significant health risk to consumers, and demand is increasing to find safe alternatives. Additionally, continued use of fungicides leads to an increase in resistance by plant pathogens, creating a need for finding biological alternatives with these pesticides. Present activities to find both natural and synthetic fungicides focus on finding compounds that are safe to humans, environment and delicate ecosystems $[4,5]$.

New antifungal compounds with distinct modes of action need to be identified because of increasing incidence of fungal resistance to existing antibiotics [6]. Plant secondary metabolites have great potential as a source of effective antifungal agents [7]. Plant-derived compounds such as hydroquinones and naphthoquinones (lapachol, juglone), sesquiterpenes (cinnamodial, capsidiol) and alkaloids (berberine) have shown diverse activities as antimicrobial and antifungal. An advantage to the approach of using ethnobotanical leads to identify compounds with antimicrobial activity [8]. For instance, leaves of Vitis vinifera are rich in tannins, flavonoids, procyanidins and also contain organic acids, lipids, enzymes and vitamins [9-12]. Furthermore, the quantitative analysis of compounds found in leaves has also been evaluated by
Monagas et al. [13]. Grape-vine leaves possesses a resistance towards several fungus diseases as Plasmopara viticola, Oidium tukeri and Botrytis cinerea which cause downy mildew, powdery mildew and fruit rot, respectively [14]. Flavonoids including quercetin and quercetin3-O-[ $\beta$-xylosyl-(1-2)- $\alpha$-rhamnoside] 4'-O- $\alpha$ - rhamnoside as bioactive compounds were secluded from Zizyphus spina-christi leaves [15]. Also, various gallic acid derivatives were isolated from the leaves of Punica granatum such 1,2,3-tri-O-galloyl- $\beta$-glucopyranose, 1,2,4-triO-galloyl- $\beta$-glucopyranose, 1,3,4-tri-O-galloyl- $\beta$-glucopyranose, 1,2,6-triO-galloyl- $\beta$-glucopyranose and 1,4,6-tri-O-galloyl- $\beta$-glucopyranose [16-18]. The main objective of the present study was to evaluate the antifungal activity of leaf extracts of various plant species against five economically important plant disease organisms under in vitro conditions with phytochemical screening and HPLC analysis.

\section{Materials and Methods}

\section{Plant materials}

Leaves of thompson seedless grape (Vitis vinifera cv. Sultana), flame seedless grape (Vitis vinifera cv. Roumy Ahmer), zizyphus (Zizyphus spina-christi cv. Willd), pomegranate (Punica granatum cv. Baladi) and fig (Ficus carica cv. Sultani), belong to families Vitaceae, Rhamnaceae,

*Corresponding author: Elsherbiny A. Elsherbiny, Plant Pathology Department Faculty of Agriculture, Mansoura University, Mansoura, Egypt, E-mail: sherbiny@mans.edu.eg, sherbiny44@hotmail.com

Received September 04, 2013; Accepted September 26, 2013; Published September 30, 2013

Citation: El-Khateeb AY, Elsherbiny EA, Tadros LK, Ali SM, Hamed HB (2013) Phytochemical Analysis and Antifungal Activity of Fruit Leaves Extracts on the Mycelial Growth of Fungal Plant Pathogens. J Plant Pathol Microb 4: 199. doi:10.4172/2157-7471.1000199

Copyright: (C $2013 \mathrm{El}$-Khateeb AY, et al. This is an open-access article distributed under the terms of the Creative Commons Attribution License, which permits unrestricted use, distribution, and reproduction in any medium, provided the original author and source are credited. 
Punicaceae and Moraceae, respectively, were used in this study. Samples were collected, cutting the leaves of plants, from the Experimental Station of the Faculty of Agriculture within the campus of the University of Mansoura, which located in the north of Egypt. Leaves were cleaned, dried in the shade, and then grounded to a fine powder using a grinding mill. Leaves powder $(3 \mathrm{Kg})$ of each plant was extracted by soaking at room temperature for six times with methanol $(30 \mathrm{~L})$. Extracts were concentrated to nearly dryness under reduced pressure by using rotary evaporator at $45^{\circ} \mathrm{C}$ to achieve the crude methanolic extracts.

\section{Plant pathogens}

Five plant pathogenic fungi, Alternaria solani, Botrytis cinerea, Botrytis fabae, Fusarium oxysporum and Fusarium solani, were isolated from diseased potato plants, diseased fruits of tomato, diseased broad bean plants, naturally infected tomato and artichoke, respectively. All the diseased plants and the diseased fruits were collected from Mansoura, Egypt. All fungal strains were grown on potato dextrose agar (PDA) or czapek agar (CZA) media and purified using single spore or hyphal tip techniques. Identification of the pure cultures was accomplished according to Barnett and Hunter [19]; Leslie and Summerell [20]; Elad et al. [21] by cultural properties, morphological and microscopical characteristics. Stock cultures of each strain were maintained on PDA at $5^{\circ} \mathrm{C}$. For use in antifungal activity assay, the fungi were subcultured onto PDA in Petri dishes ( $9 \mathrm{~cm}$ diameter), and incubated at $25^{\circ} \mathrm{C}$ for $7-10 \mathrm{~d}$.

\section{Preliminary phytochemical tests of crude plant extracts}

Crude extracts were analyzed to detect the presence of terpenes, tannins, flavonoids, saponins, alkaloids, carbohydrate and/or glucosides, phenolic glucosides and resins according to Harborne [22].

\section{Determination of total polyphenols and total flavonoids con-} tent

Total phenolics content of air dried leaves were determined by Folin-Ciocalteau method according to Lin and Tang [23]. Gallic acid was chosen as standard of total phenolics for making the standard curve (200-1600 mg/l). Concentration of total phenolics content expressed as milligram gallic acid equivalents GAE/g. Total flavonoids content of air dried leaves were determined using aluminum chloride colorimetric method, which described by Chang et al. [24]. Quercetin was chosen for making standard curve of flavonoids $(0-50 \mathrm{mg} / \mathrm{l})$. Concentration of total flavonoids content was expressed as milligram quercetin equivalents QE/g.

\section{Identification of polyphenols by HPLC}

Phenolic compounds of plant samples were extracted according to Ben-Hammouda et al. [25]. Identification of individual phenolic compounds of plant samples was performed on a Hewlett-Packard HPLC (Model 1100), using a hypersil $\mathrm{C}_{18}$ reversed phase column $(250 \times 4.6 \mathrm{~mm})$ with $5 \mu \mathrm{m}$ particle size. Injection by means of Rheodyne injection valve (Model 7125) with $50 \mu \mathrm{m}$ fixed loop. Phenolic compounds of each sample were identified by comparing their relative retention times with those of the standards mixture chromatogram. The concentration of an individual compounds was calculated on the basis of peak area measurements.

\section{Antifungal activity of plant extracts on the mycelial growth of test fungi}

Extracts were dissolved in dimethyl sulphoxide (DMSO) and added to PDA medium immediately before it was poured into Petri dishes ( 9 $\mathrm{cm}$ diameter) at $40-45^{\circ} \mathrm{C}$ to obtain a series of concentrations $(1,2$ and $4 \mathrm{mg} / \mathrm{ml}$ ). Control plates were treated with DMSO alone, and three replicates per treatment were used. Plates were incubated at $25 \pm 2^{\circ} \mathrm{C}$. Colony growth diameter was measured after the fungal growth in the control treatment had completely covered Petri dishes. Percentage of mycelial growth inhibition was calculated from the formula: Mycelial growth inhibition $=[($ diameter of control-diameter of sample $) /$ diameter of control $] \times 100$

\section{Statistical analysis}

Statistical analyses of all experimental data were done using the statistical software package CoStat [26]. All comparisons were first subjected to one way analysis of variance (ANOVA) and significant differences between treatment means were determined using Duncan's multiple range test at $P<0.05$ as the level of the significance [27].

\section{Results and Discussion}

\section{Preliminary phytochemical tests of crude methanolic extracts}

All crude methanolic extracts of leaves were rich in terpenes, tannins, flavonoids, alkaloids, carbohydrate or glycosides, phenolic glycosides and resins. In contrast, all leaves extracts was poor in saponins except zizyphus and fig, (Table 1). Results for thompson and flame seedless leaves were agreed with Bombardelli and Morazzonni [9]; Hebash et al. [10] and Hmamouchi et al. [11]. Felicio et al. [12] found that the Vitis vinifera leaves were rich in tannins, flavonoids, procyanidins and contain organic acids, lipids, enzymes and vitamins. Present data for zizyphus leaves extract was agreed with Ikram et al. [28]; Higuchi et al. [29]; Nawwar et al. [30]; Han et al. [31]; Barboni et al. [32]; AbuZarga et al. [33]; Cheng et al. [34] and Shahat et al. [15]. Tripathi et al. [35] identified peptide and cyclopeptide alkaloids, flavonoids, sterols, tannins, betulinic acid and triterpenoidal saponin glycosides from the different species of the genus Zizyphus. Furthermore, Mahran et al. [36] isolated four triterpenoidal saponin glycosides namely christinin-A (the major saponin), B, C and D from butanol extract of Zizyphus spinachristi leaves growing in Egypt.

Results of pomegranate leaves were in agreement with Nawwar et al. [17] and Hussein et al. [18]. They isolated gallotannins and ellagitannins namely; brevifolin carboxylic acid, corilagin, brevifolin, ellagic acid, granatin- $B$ and punicafolin from the leaf extract of Egyptian Punica granatum. Data of methanolic extract of fig leaves was

\begin{tabular}{|c|c|c|c|c|c|c|c|c|}
\hline Plant & Terpens & Tannins & Flavonoids & Saponins & Alkaloids & $\begin{array}{l}\text { Carbohydrate or } \\
\text { Glycosides }\end{array}$ & Phenolic glycosides & Resins \\
\hline Thompson seedless & ++ & + & ++ & - & + & ++ & ++ & ++ \\
\hline Flame seedless & +++ & + & ++ & - & + & ++ & ++ & ++ \\
\hline Zizyphus & +++ & + & ++ & +++ & + & ++ & ++ & ++ \\
\hline Pomegranate & +++ & + & ++ & - & + & ++ & ++ & ++ \\
\hline Fig & + & +++ & ++ & + & + & ++ & + & ++ \\
\hline
\end{tabular}

$(+)$ detected, (-) not detected

Table 1: Preliminary phytochemical tests of crude methanolic extracts. 
in accordance with Ahmed et al. [37]. They fractionated two triterpenes from ethanolic extract of fresh leaves of Ficus carica L. into hexane soluble and insoluble fractions. Also, Ayinde et al. [38] found that the aqueous extract of Ficus exasperata vahl leaves showed the presence of flavonoids, saponins and tannins, with no traces of alkaloids or anthraquinones.

\section{Total polyphenols and total flavonoids content}

Total polyphenols include several classes of phenolic compounds that are secondary plant metabolites and integral part of human and animal diets. Flavonoids are a large group of the phenolic compounds consisting mainly of flavonols, flavanols and anthocyanins. Phenolic compounds can play an important role in preventing body cells and organs from injuries by hydrogen peroxide, damage by lipid peroxides and scavenging or neutralizing free radicals [39]. It has been reported that free radical scavenging and antioxidant activity of many medicinal plants are responsible for their therapeutic effect against cancer, diabetes, tissue inflammatory and cardiovascular diseases [40]. Also, it was found that high total phenols content increase antioxidant activity and there is a linear correlation between phenolic content and antioxidant activity in fig leaves extract [41].

Zizyphus leaves had the highest concentration of total polyphenols (147.47 mgGAE/g). Also, pomegranate and fig leaves had high values, which were 122.52 and $123.51 \mathrm{mgGAE} / \mathrm{g}$, respectively. For total flavonoids, zizyphus leaves contained the highest amount (16.35 $\mathrm{mgQE} / \mathrm{g}$ ) followed by flame seedless leaves by $15.93 \mathrm{mgQE} / \mathrm{g}$. Whereas, thompson seedless and pomegranate leaves contained 13.25 and 10.95 $\mathrm{mgQE} / \mathrm{g}$, respectively (Table 2).

These results are in agreement with Monagas et al. [13]. They found that the total polyphenols was $112 \pm 18 \mathrm{mgGAE} / \mathrm{g}$ of methanolic extract of Vitis vinifera leaves. Additionally, Orhan et al. [42] suggested that the total phenolic contents of $V$. vinifera leaves were $205.79 \pm 8.89,57.17 \pm$ 6.5 and $37.97 \pm 0.90 \mathrm{mgGAE} / \mathrm{g}$ for ethyl acetate, butanol and remaining aqueous fractions, respectively. Also, Orha et al. [43] suggested that the total phenolic contents of $V$. vinifera leaves were 89.4, 216.0, 91.2 and $68.6 \mathrm{mgGAE} / \mathrm{g}$ for chloroform, ethyl acetate, butanol and remaining aqueous fractions, respectively. Although, chloroform and ethyl acetate fractions contain 59 and $206 \mathrm{mgQE} / \mathrm{g}$ of total flavonoids, respectively, total flavonoids were not detected in butanol fraction and remaining aqueous fraction had a traces of total flavonoids. While, Aseri et al. [44] represented that the total phenols content was $1.81 \mathrm{mg} / \mathrm{g}$ in control Punica granatum leaves on fresh weight basis. Pari and Suresh [45] showed that the ethanolic extract of grape leave contain phenolic compounds in a concentration of $98.84 \pm 9.29 \mathrm{mgGAE} / \mathrm{g}$. Allam et al. [46] found that 20, 40 and $60 \mathrm{mg}$ of fig leaves aqueous extract contain $3.05,6.10$ and $9.14 \mathrm{mg} / \mathrm{g}$ extract of total phenols, respectively. While, the previous amounts of the extracts contain $0.22,0.45$ and $0.67 \mathrm{mg} / \mathrm{g}$ extract of total flavonoids, respectively.

\begin{tabular}{|l|c|c|}
\hline Leaves extract & $\begin{array}{c}\text { Total polyphenols } \\
\text { (mgGAE/g) }\end{array}$ & $\begin{array}{c}\text { Total flavonoids } \\
\text { (mgQE/g) }\end{array}$ \\
\hline Thompson seedless & 119.82 & 13.25 \\
\hline Flame seedless & 117.51 & 15.93 \\
\hline Zizyphus & 147.47 & 16.35 \\
\hline Pomegranate & 122.52 & 10.95 \\
\hline Fig & 123.51 & 9.57 \\
\hline
\end{tabular}

Table 2: Total polyphenols (mgGAE/g) and total flavonoids (mgQE/g) contents of leaves extracts.

\section{Identification of polyphenols by HPLC}

Twelve polyphenolic compounds were available as authentic samples namely: pyrogallic acid, gallic acid, protocatechuic, catechin, $p$-hydroxy benzoic acid, $p$-coumaric acid, phenol, $o$-coumaric acid, salicylic acid, coumarin, quercetin and cinnamic acid. These standard samples were used to identify the corresponding components in leaves polyphenols. Results revealed that the twenty four, twenty six, thirty three, twenty seven and twenty one compounds with different retention times were recognized in HPLC chromatogram of thompson seedless, flame seedless, zizyphus, pomegranate and fig leaves, respectively. All leaves samples contained protocatechuic, catechin, $p$-hydroxy benzoic acid, $p$-coumaric acid, $o$-coumaric acid and coumarin with different concentrations comparing with standard compounds. Also, $p$-coumaric acid was the predominant identified component in both thompson seedless and flame seedless leaves in concentrations of 14.761 and $44.732 \%$, followed by phenol (10.031 and $4.179 \%$ ), whereas, phenol was the main component of polyphenols in zizyphus leaves in concentration of $9.896 \%$ followed by $p$-coumaric acid (5.253\%), pyrogallic acid (5.089\%) and $p$-hydroxy benzoic acid (2.592\%). Although, $p$-hydroxy benzoic acid was the major identified phenolic component in both pomegranate and fig leaves in concentrations of 27.587 and $7.736 \%$, while, catechin had the second level (15.243\%) in pomegranate leaves and pyrogallic acid had the second rank (4.775\%) in fig leaves, (Table 3). Gallic acid and quercetin was not found in thompson seedless, flame seedless, zizyphus and fig leaves, while, pomegranate leaves had 2.264 and $0.286 \%$ of gallic acid and quercetin. Cinnamic acid was absent in pomegranate and fig leaves but was identified in thompson seedless, flame seedless and zizyphus at concentrations of $0.086,0.176$ and $0.071 \%$, respectively.

Several authors identified some polyphenoilc derivatives from leaves of $V$. vinifera. For example, Hmamouchi et al. [11] isolated ten hydroxy flavonoids including quercetin-3-rhamnogalactoside, quercetin and caffeic acid, while, Wirth et al. [47] analyzed the released aglycons to identify five aglycon chemical groups including methyl salicylate, 1-phenylethanol, 2-phenylethanol, benzyl alcohol, phenol, 3,4,5-trimethoxyphenol and 4-(4-hydroxyphenyl) butan-2ol. In addition, Monagas et al. [13] found that phenolic composition of commercial dietary ingredients of $\mathrm{V}$. vinifera leaves contain anthocyanins including delphinidin-3-(6-P-coumaroyl) glucoside, cyanidin-3-(6-P-coumaroyl) glucoside, petunidin-3-(6-P-coumaroyl) glucoside, peonidin-3-(6-P-coumaroyl) glucoside and malvidin-3(6-P-coumaroyl) glucoside. Also, flavonols as well as quercetin-3-Ogalactoside, quercetin-3-O-glucuronide, quercetin-3-O-glucoside and quercetin were identified while, trans-caftaric acid was the only hydroxycinnamic acid derivative identified. Furthermore, Shahat et al. [15] secluded the flavonoids including quercetin, and quercetin-3-O-[ $\beta$-xylosyl-(1-2)- $\alpha$-rhamnoside] 4'-O- $\alpha$-rhamnoside as bioactive compounds of $Z$. spina-christi leaves. Also, various gallic acid derivatives were isolated from the leaves of Punica granatum such as 1,2,3-tri-O-galloyl- $\beta$-glucopyranose, 1,2,4-tri-O-galloyl- $\beta$ glucopyranose, 1,3,4-tri-O-galloyl- $\beta$-glucopyranose, 1,2,6-tri-O-galloyl$\beta$-glucopyranose and 1,4,6-tri-O-galloyl- $\beta$-glucopyranose [16-18]. Kash [48] found that mulberry leaves (family Moraceae) contain pyrogallic acid, protocatechuic, catechin, p-hydroxy benzoic acid, p-coumaric acid, O-coumaric acid, salicylic acid and coumarin with concentrations of $5.683,1.089,11.238,2.741,13.874,1.541,0.778$ and $0.610 \%$, respectively. Results revealed that fifteen, sixteen, twenty three, eighteen and thirteen unknown compounds with different retention times were appeared in HPLC chromatogram of thompson seedless, flame seedless, zizyphus, pomegranate and fig leaves, respectively. 
Citation: El-Khateeb AY, Elsherbiny EA, Tadros LK, Ali SM, Hamed HB (2013) Phytochemical Analysis and Antifungal Activity of Fruit Leaves Extracts on the Mycelial Growth of Fungal Plant Pathogens. J Plant Pathol Microb 4: 199. doi:10.4172/2157-7471.1000199

Page 4 of 6

\begin{tabular}{|c|c|c|c|c|c|c|c|c|c|c|}
\hline \multirow[t]{2}{*}{ Compounds } & \multicolumn{2}{|c|}{ Thompson seedless } & \multicolumn{2}{|c|}{ Flame seedless } & \multicolumn{2}{|c|}{ Zizyphus } & \multicolumn{2}{|c|}{ Pomegranate } & \multirow{2}{*}{$\begin{array}{c}\text { Fig } \\
\text { Rt }\end{array}$} & \multirow[b]{2}{*}{$\%$} \\
\hline & $\mathrm{Rt}$ & $\%$ & $\mathrm{Rt}$ & $\%$ & Rt & $\%$ & $\mathrm{Rt}$ & $\%$ & & \\
\hline Pyrogallic acid & 22.298 & 1.722 & 20.890 & 2.849 & 20.993 & 5.089 & - & - & 22.199 & 4.775 \\
\hline Gallic acid & - & - & - & - & - & - & 23.541 & 2.264 & - & - \\
\hline Protocatechuic & 27.959 & 3.140 & 29.698 & 1.186 & 27.878 & 2.136 & 29.050 & 0.607 & 28.797 & 1.433 \\
\hline Catechin & 32.981 & 0.824 & 31.482 & 1.487 & 32.685 & 0.541 & 31.996 & 15.243 & 32.204 & 1.272 \\
\hline p-hydroxy benzoic acid & 35.493 & 1.983 & 34.293 & 1.017 & 35.412 & 2.592 & 35.126 & 27.587 & 34.477 & 7.736 \\
\hline P-coumaric acid & 38.311 & 14.761 & 37.585 & 44.732 & 38.354 & 5.253 & 37.796 & 5.570 & 37.669 & 3.042 \\
\hline Phenol & 40.183 & 10.031 & 40.270 & 4.179 & 39.469 & 9.896 & 40.582 & 3.687 & - & - \\
\hline O-coumaric acid & 42.874 & 8.730 & 43.399 & 1.028 & 42.921 & 1.256 & 42.852 & 2.429 & 42.393 & 1.109 \\
\hline Salicylic acid & - & - & 45.346 & 0.543 & 44.197 & 1.652 & - & - & 45.460 & 0.928 \\
\hline Coumarin & 46.402 & 3.854 & 47.072 & 1.136 & 46.423 & 2.281 & 46.101 & 1.126 & 47.783 & 0.204 \\
\hline Quercetin & - & - & - & - & - & - & 49.862 & 0.286 & - & - \\
\hline Cinnamic acid & 53.337 & 0.086 & 51.450 & 0.176 & 51.675 & 0.071 & - & - & - & - \\
\hline
\end{tabular}

Table 3: Polyphenols compounds determined by HPLC in crude methanolic extracts.

\begin{tabular}{|c|c|c|c|c|c|c|c|c|c|c|c|c|c|c|c|}
\hline \multirow[t]{3}{*}{ Leaves extract } & \multicolumn{15}{|c|}{ Inhibition \% } \\
\hline & \multicolumn{3}{|c|}{ Alternaria solani } & \multicolumn{3}{|c|}{ Botrytis cinerea } & \multicolumn{3}{|c|}{ Botrytis fabae } & \multicolumn{3}{|c|}{ Fusarium oxysporum } & \multicolumn{3}{|c|}{ Fusarium solani } \\
\hline & $1 \mathrm{mg} / \mathrm{ml}$ & $2 \mathrm{mg} / \mathrm{ml}$ & $4 \mathrm{mg} / \mathrm{ml}$ & $1 \mathrm{mg} / \mathrm{ml}$ & $2 \mathrm{mg} / \mathrm{ml}$ & $4 \mathrm{mg} / \mathrm{ml}$ & $1 \mathrm{mg} / \mathrm{ml}$ & $2 \mathrm{mg} / \mathrm{ml}$ & $4 \mathrm{mg} / \mathrm{ml}$ & $1 \mathrm{mg} / \mathrm{ml}$ & $2 \mathrm{mg} / \mathrm{ml}$ & $4 \mathrm{mg} / \mathrm{ml}$ & $1 \mathrm{mg} / \mathrm{ml}$ & $2 \mathrm{mg} / \mathrm{ml}$ & $4 \mathrm{mg} / \mathrm{ml}$ \\
\hline $\begin{array}{l}\text { Thompson } \\
\text { seedless }\end{array}$ & $44.44 \mathrm{~d} 1$ & $53.33 d$ & $61.11 \mathrm{e}$ & $42.22 \mathrm{~d}$ & $50.00 \mathrm{e}$ & $63.33 \mathrm{e}$ & $52.22 \mathrm{~d}$ & $68.89 \mathrm{~d}$ & $78.89 \mathrm{~d}$ & $15.56 \mathrm{~d}$ & $24.44 \mathrm{~d}$ & $37.78 \mathrm{e}$ & $17.78 \mathrm{e}$ & $25.56 \mathrm{e}$ & $40.00 \mathrm{~d}$ \\
\hline Flame seedless & $44.44 d$ & $57.78 \mathrm{~d}$ & $70.00 \mathrm{~d}$ & $47.78 \mathrm{c}$ & $60.00 \mathrm{~d}$ & $72.22 \mathrm{~d}$ & $55.56 \mathrm{~d}$ & $71.11 \mathrm{c}$ & $84.44 \mathrm{c}$ & $17.78 \mathrm{~d}$ & $27.78 \mathrm{~d}$ & $41.11 \mathrm{~d}$ & $20.00 \mathrm{~d}$ & $33.33 d$ & $51.11 \mathrm{c}$ \\
\hline Zizyphus & $63.33 \mathrm{a}$ & $75.56 \mathrm{a}$ & $91.11 \mathrm{a}$ & $67.78 \mathrm{a}$ & $77.78 \mathrm{a}$ & $92.22 \mathrm{a}$ & $64.44 \mathrm{a}$ & $81.11 \mathrm{a}$ & $95.56 \mathrm{a}$ & $45.56 \mathrm{a}$ & $55.56 \mathrm{a}$ & $64.44 \mathrm{a}$ & $50.00 \mathrm{a}$ & $57.78 \mathrm{a}$ & $70.00 \mathrm{a}$ \\
\hline Pomegranate & $61.11 b$ & $71.11 b$ & $86.67 \mathrm{~b}$ & $66.67 \mathrm{a}$ & $75.56 \mathrm{~b}$ & $90.00 \mathrm{~b}$ & $62.22 \mathrm{~b}$ & $77.78 \mathrm{~b}$ & $94.44 \mathrm{a}$ & $38.89 \mathrm{~b}$ & $47.78 \mathrm{~b}$ & $57.78 \mathrm{~b}$ & $42.22 \mathrm{~b}$ & $48.89 \mathrm{~b}$ & $58.89 \mathrm{~b}$ \\
\hline Fig & $56.67 \mathrm{c}$ & $66.67 \mathrm{c}$ & $77.78 \mathrm{c}$ & $61.11 b$ & $70.00 \mathrm{c}$ & $82.22 \mathrm{c}$ & $58.89 \mathrm{c}$ & $72.22 \mathrm{c}$ & $91.11 b$ & $31.11 \mathrm{c}$ & $38.89 \mathrm{c}$ & $46.67 \mathrm{c}$ & $34.44 \mathrm{c}$ & $42.22 \mathrm{c}$ & $51.11 \mathrm{c}$ \\
\hline
\end{tabular}

${ }^{1}$ Values within a column followed by a different letter are significantly different according to Duncan's multiple range test $(P=0.05)$

Table 4: Effect of methanolic leaves extracts on mycelial growth of tested fungi.

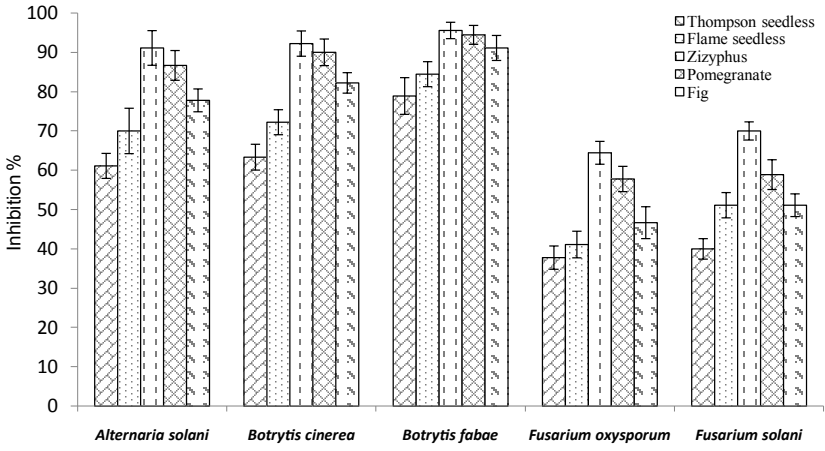

Figure 1: Effect of methanolic leaves extracts on mycelial growth of tested fungi (mean \pm s.e) at the concentration of $4 \mathrm{mg} / \mathrm{ml}$.

There were no available authentic samples to identify these unknown compounds which may be some polyphenolic derivatives.

\section{Antifungal activity of plant extracts on the mycelial growth of test fungi}

All methanolic leaves extracts showed an extensive antifungal activity against the different fungal pathogens tested (Table 4). However, fungal sensitivity varied according to the species. Extract of zizyphus significantly reduced the mycelial growth of all tested fungi from 64.44 (for F. oxysporum) to $95.56 \%$ (for B. fabae) at the concentration of 4 $\mathrm{mg} / \mathrm{ml}$ (Figure 1). These were followed by pomegranate extract, which caused a significant decrease on the fungal growth ranged from 57.78 (F. oxysporum) to $94.44 \%$ (B. fabae) at the same concentration (Figure 1). There was no significant difference between inhibitory effects of zizyphus and pomegranate on the growth of $B$. fabae at $4 \mathrm{mg} / \mathrm{ml}$. Also, extracts of zizyphus followed by pomegranate were the most effective among the plant species tested against the growth of the fungi at the concentrations of 1 and $2 \mathrm{mg} / \mathrm{ml}$ (Figures 2 and 3). Extract of flame seedless had more effectual antifungal than thompson seedless at all concentrations. F. oxysporum and F. solani showed high resistance for all methanolic extracts (Table 4). In general, There were positive relationships between the concentration of the methanol extracts and the inhibition rate on mycelia growth of all tested fungi.

According with the obtained results for HPLC analysis, ten polyphenols compounds have been identified in the methanolic extract of zizyphus leaves, besides; the main component found in this extract was phenol. The high antifungal activity of zizyphus extract is possibly due to phenolic compounds. Phenolic compounds are one of the major families of secondary metabolites in plants, and they are of nearly 10,000 individual compounds [49]. Phenolic or polyphenol can be defined chemically as a substance which possesses a benzene ring with one or more hydroxyl groups, with evidence that increased hydroxylation results in increased toxicity [50]. These polyphenols are very important for plants to contribute to resistance to microorganisms, herbivores and insects [51]. Generally, the active antifungal compounds of most plant extracts are phenolic compounds. This may be due to that their antifungal mode of action might be related to that of other compounds.

These results were agreed with Brown and Morra [52] and NitaLazar et al. [53]. They suggested that the activation of the phenolic pathway is known in the plant physiology to be part of the defense response against phytopathogenic microorganisms. Also, Sisti et al. [54] showed that the phenolic agents are active against pathogenic microorganisms for humans and animals.

Many potential modes of action by which phenolics counteract envelopment of pathogenic agents have been suggested, from the impairment of enzymatic processes involved in energy production and structural component synthesis by weakening or destroying the 
Citation: El-Khateeb AY, Elsherbiny EA, Tadros LK, Ali SM, Hamed HB (2013) Phytochemical Analysis and Antifungal Activity of Fruit Leaves Extracts on the Mycelial Growth of Fungal Plant Pathogens. J Plant Pathol Microb 4: 199. doi:10.4172/2157-7471.1000199

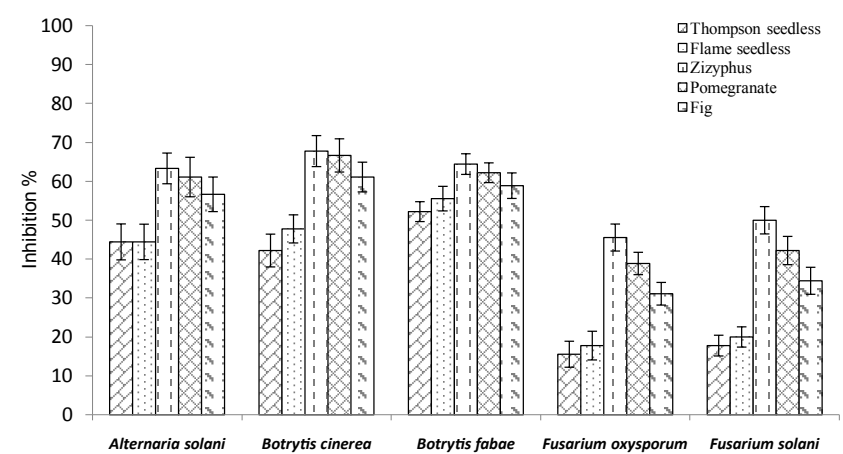

Figure 2: Effect of methanolic leaves extracts on mycelial growth of tested fungi (mean \pm s.e) at the concentration of $1 \mathrm{mg} / \mathrm{ml}$.

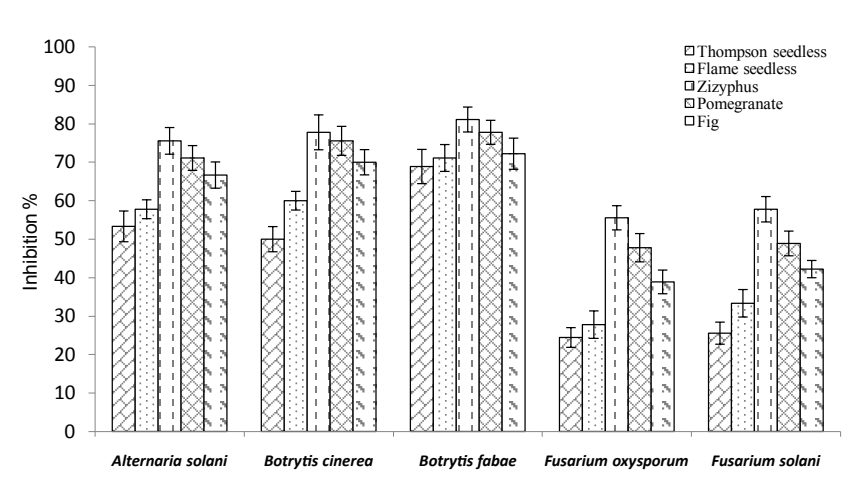

Figure 3: Effect of methanolic leaves extracts on mycelial growth of tested fungi (mean \pm s.e) at the concentration of $2 \mathrm{mg} / \mathrm{ml}$.

permeability barrier of the cell membrane by altering the physiological status of the cells or affecting nucleic acids synthesis [55]. In the same way, Galvan et al. [8] mentioned that plant secondary metabolites have great potential as a source of effective antifungal agents, for example, plant-derived compounds such as hydroquinones, naphthoquinones, alkaloids and flavonoids, have shown diverse antimicrobial activities including antifungal activities. Batovska et al. [14] found that the grapevine leaves possess a resistance towards several fungi, Plasmopara viticola, Oidium tukeri and Botrytis cinerea as biomarkers for the fungal resistance.

\section{References}

1. Research Council, Board of Agriculture (1987) Regulating Pesticides in FoodThe Delaney Paradox. National Academy Press, Washington DC, USA.

2. Tegegnea G, Pretoriusa JC, Swart WJ (2008) Antifungal properties of Agapanthus africanus L. extracts against plant pathogens. Crop Protection 27 1052-1060.

3. Castillo F, Hernandeza D, Gallegosa G, Mendezb M, Rodriguezb R, et al. (2010) In vitro antifungal activity of plant extracts obtained with alternative organic solvents against Rhizoctonia solani Kühn. Industrial Crops and Products 32: 324-328.

4. Wilson CL, Solar JM, EL-Ghaouth A, Wisniewski ME (1997) Rapid evaluation of plant extracts and essential oils for antifungal activity against Botrytis cinerea. Plant Disease 81: 204-210.

5. Gahukar RT (2012) Evaluation of plant-derived products against pests and diseases of medicinal plants: A review. Crop Protection 42: 202-209.

6. Loeffler J, Stevens DA (2003) Antifungal drug resistance. Clin Infect Dis 36 S31-S41.

7. Rocha AD, de Oliveira AB, de Souza Filho JD, Lombardi JA, Braga FC (2004)
Antifungal constituents of Clytostoma ramentaceum and Mansoa hirsuta. Phytother Res 18: 463-467.

8. Galván IJ, Mir-Rashed N, Jessulat M, Atanya M, Golshani A, et al. (2008) Antifungal and antioxidant activities of the phytomedicine pipsissewa, Chimaphila umbellata. Phytochemistry 69: 738-746.

9. Bombardelli E, Morazzonni P (1995) Vitis vinifera L. Fitoterapia 66: 291-317.

10. Hebash KH, Fadel HM, Soliman MA (1991) Volatile components of grape leaves. Journal of Islamic Academy of Sciences 4: 26-28.

11. Hmamouchi M, Safi N, Essassi EM (1997) Oligomeric and polymeric proanthocyanidins from Moroccan grapewine (Vitis vinifera) leaves. Fitoterapia 68: $332-337$

12. Felicio JD, Santos R, Goncalez E (2001) Chemical Constituents from Vitis vinifera (Vitaceae), 68. Arquivos Do Instituto Biologico, Sao Paulo 470-50.

13. Monagas M, Hernández-Ledesma B, Gómez-Cordovés C, Bartolomé B (2006) Commercial dietary ingredients from Vitis vinifera $\mathrm{L}$. leaves and grape skins: antioxidant and chemical characterization. J Agric Food Chem 54: 319-327.

14. Batovska DI, Todorova IT, Nedelcheva DV, Parushev SP, Atanassov AI, et al (2008) Preliminary study on biomarkers for the fungal resistance in Vitis vinifera leaves. J Plant Physiol 165: 791-795.

15. Shahat AA, Pieters L, Apers S, Nazeif NM, Abdel-Azim NS, et al. (2001) Chemical and biological investigations on Zizyphus spina-christi L. Phytother Res 15: 593-597.

16. Tanaka T, Nonaka G, Nishioka I (1985) Punicafolin, an ellagitannin from the leaves of Punica granatum. Phytochemistry 24: 2075-2078.

17. Nawwar MH, Hussein SM, Merfort I (1994) NMR spectral analysis of polyphenols from Punica granatum. Phytochemistry 36: 793-798.

18. Hussein SM, Barakat HH, Merfort I, Nawwar MM (1997) Tannins from the leaves of punica granatum. Phytochemisty 45: 819-823.

19. Barnett HL, Hunter BB (1998) Illustrated Genera of Imperfect Fungi. (4thedn), APS Press, Minncapolis, Minesota, USA.

20. Leslie JF, Summerell BA (2006) The Fusarium laboratory manual. Blackwell Publishing Professional, Ames, lowa, USA.

21. Elad Y, Williamson B, Tudzynski P, Delen N (2007) Botrytis: Biology, Pathology and Control, Springer Science, Dordrecht, The Netherlands.

22. Harborne JB (1984) Phytochemical methods. (2ndedn), A guide to modern techniques of plant analysis). Chapman and Hall Publishing, New York, USA.

23. Lin JY, Tang CY (2007) Determination of total phenolic and flavonoid contents in selected fruits and vegetables, as well as their stimulatory effects on mouse splenocyte proliferation. Food Chemistry 101: 140-147.

24. Chang CC, Yang MH, Wen HM, Chern JC (2002) Estimation of total flavonoid content in propolis by two complementary colorimetric methods. Journal of Food and Drug Analysis 10: 178-182.

25. Ben-Hammouda M, Kremer RJ, Minor HC, Sarwar M (1995) A chemical basis for differential allelopathic potential of sorghum hybrids on wheat. J Chem Ecol 21: $775-786$

26. http://www.cohort.com

27. Duncan D (1955) Multiply range and multiple F test. Biometrics 11: 1-42.

28. Ikram M, Ogihara Y, Yamasaki K (1981) Structure of a new saponin from Zizyphus vulgaris. Journal of Natural Products 44: 91-93.

29. Higuchi R, Kubota S, Komori T, Kawasaki T, Pardey VB, et al. (1984) Triterpenoid saponins from the bark of Zizyphus joazeiro. Phytochemistry 23: 2597-2600.

30. Nawwar MM, Ishak MS, Michael HN, Buddrus J (1984) Leaf flavonoid of Zizyphus spina-christi. Phytochemistry 23: 2110-2111.

31. Han BH, Park MH, Han YN (1990) Cyclic peptide and peptide alkajloids from seeds of Zizyphus vulgaris. Phytochemistry 29: 3315-3319.

32. Barboni L, Gariboldi P, Torregiani E, Verotta L (1994) Cyclopeptide alkaloid from Zizyphus mucronata. Phytochemistry 35: 1579-1582.

33. Abu-Zarga M, Sabri S, al-Aboudi A, Ajaz MS, Sultana N, et al. (1995) New cyclopeptide alkaloids from Ziziphus lotus. J Nat Prod 58: 504-511. 
Citation: El-Khateeb AY, Elsherbiny EA, Tadros LK, Ali SM, Hamed HB (2013) Phytochemical Analysis and Antifungal Activity of Fruit Leaves Extracts on the Mycelial Growth of Fungal Plant Pathogens. J Plant Pathol Microb 4: 199. doi:10.4172/2157-7471.1000199

34. Cheng G, Bai Y, Zhao Y, Tao J, Liu Y, et al. (2000) Flavonoids from Zizyphus jujuba Mill var. spinosa. Tetrahedron 56: 8915-8920.

35. Tripathi M, Pandey MB, Jha RN, Pandey VB, Tripathi PN, et al. (2001) Cyclopeptide alkaloids from Zizyphus jujuba. Fitoterapia 72: 507-510.

36. el-Din Hussein Mahran G, Glombitza KW, Mirhom YW, Hartmann R, Michel CG (1996) Novel Saponins from Zizyphus spina-christi growing in Egypt. Planta Med 62: 163-165.

37. Ahmed W, Khan AQ, Malik A (1988) Two triterpenes from the leaves of Ficus carica. Planta Med 54: 481.

38. Ayinde BA, Omogbai EK, Amaechina FC (2007) Pharmacognosy and hypotensive evaluation of Ficus exasperata Vahl (Moraceae) leaf. Acta Pol Pharm 64: 543-546.

39. Sroka Z, Cisowski W (2003) Hydrogen peroxide scavenging, antioxidant and anti-radical activity of some phenolic acids. Food Chem Toxicol 41: 753-758.

40. Cai Y, Luo Q, Sun M, Corke H (2004) Antioxidant activity and phenolic compounds of 112 traditional Chinese medicinal plants associated with anticancer. Life Sci 74: 2157-2184.

41. Changwei AO, Anping L, Abdelnaser A, Tran DX, Shinkichi T (2008) Evaluation of antioxidant and antibacterial activities of Ficus microcarpa L. leaf extract. Food Control 19: 940-948.

42. Orhan N, Aslan M, Orhan DD, Ergun F, Yeşilada E (2006) In-vivo assessment of antidiabetic and antioxidant activities of grapevine leaves (Vitis vinifera) in diabetic rats. J Ethnopharmacol 108: 280-286.

43. Orhan DD, Orhan N, Ergun E, Ergun F (2007) Hepatoprotective effect of Vitis vinifera $\mathrm{L}$. leaves on carbon tetrachloride-induced acute liver damage in rats. $J$ Ethnopharmacol 112: 145-151.

44. Aseri GK, Jain N, Panwar J, Rao AV, Meghwal PR (2008) Biofertilizers improve plant growth, fruit yield, nutrition, metabolism and rhizosphere enzyme activities of Pomegranate (Punica granatum L.) in Indian Thar Desert. Scientia Horticulturae 117: 130-135.
45. Pari L, Suresh A (2008) Effect of grape (Vitis vinifera L) leaf extract on alcohol induced oxidative stress in rats. Food Chem Toxicol 46: 1627-1634.

46. Allam SO, Nematalla KM, Khalil EM (2008) Effect of aqueous fig leaves extract as hypoglycemic agent. J Agric Sci Mansoura Univ 33: 8617-8629.

47. Wirth J, Guo W, Baumes R, Günata Z (2001) Volatile compounds released by enzymatic hydrolysis of glycoconjugates of leaves and grape berries from Vitis vinifera Muscat of Alexandria and Shiraz cultivars. J Agric Food Chem 49: 2917-2923.

48. Kash SA (2009) Chemical and biochemical studies on mulberry plant. M.Sc Thesis, Agri Chem. Dept Fac of Agric, Mansoura Univ, Mansoura, Egypt.

49. Arif T, Bhosale JD, Kumar N, Mandal TK, Bendre RS, et al. (2009) Natural products--antifungal agents derived from plants. J Asian Nat Prod Res 11: 621638.

50. Ruiz-Garcia Y, Gomez-Plaza E (2013) Elicitors: a tool for improving fruit phenolic content. Agriculture 3: 33-52.

51. Hammerschmidt R (2005) Phenols and plantepathogen interactions: the saga continues. Physiol. Mol. Plant Pathol. 66: 77-78.

52. Brown PD, Morra MJ (1997) Control of soil-borne plant pests using glucosinolate containing plants. Advances in Agronomy 61: 167-231.

53. Nita-Lazar M, Heyraud A, Gey C, Braccini I, Lienart Y (2004) Nove oligosaccharides isolated from Fusarium oxysporum L. rapidly induce PAL activity in Rubus cells. Acta Biochim Pol 51: 625-647.

54. Sisti M, De-Santi M, Fraternale D, Ninfali P, Scoccianti V, et al. (2008) Antifungal activity of Rubus ulmifolius Schott standardized in vitro culture. LWT 41: 946 950

55. Cutter CN (2000) Antimicrobial effect of herb extracts against Escherichia coli O157:H7, Listeria monocytogenes, and Salmonella typhimurium associated with beef. J Food Prot 63: 601-607. 